\title{
A revision of the Jurassic (Bathonian to Oxfordian) lithostratigraphy of the onshore Moray Firth Basin, north-east Scotland
}

\author{
A.J. Mark Barron*, James B. Riding \\ British Geological Survey, Environmental Science Centre, Keyworth, Nottingham NG12 \\ $5 G G, U K$ \\ * Corresponding author. \\ E-mail address: ajmb@bgs.ac.uk (A.J.M. Barron). Telephone: +44(0)115 9363170
}

\begin{abstract}
Bathonian to Oxfordian strata occur onshore in two principal locations over $30 \mathrm{~km}$ apart on the coast of the Moray Firth, at Brora and Balintore. The existing lithostratigraphy has the same formation names applied to both successions despite profound differences, exemplified in their schemes of local members. Furthermore, three of the formation names include the same place name, and use obsolete lithological terms.
\end{abstract}

We consider that all the Bathonian to Oxfordian members are satisfactory, and propose their retention with original names, with one exception, to provide continuity with the superseded formational scheme. We propose retention of the Brora Coal Formation as currently defined.

The Brora Argillaceous, Brora Arenaceous and Balintore formations at Brora are unsatisfactory in a modern context and we propose:

i) a new Strathsteven Mudstone Formation, which is mudstone-dominated, and generally coarsens-upwards.

ii) a Clynekirkton Sandstone Formation, which is sandstone-dominated and generally coarsens upwards.

This formation scheme employs unique geographical names and modern and appropriate lithological terminology. Furthermore, the boundary between the Strathsteven and Clynekirkton formations is placed at a junction that is a change from mud- and silt-dominated lithologies to silt- and fine- and medium-grained sand and is mappable.

We consider that the Callovian-Oxfordian succession at Balintore should be assigned to a single formation, viz. the revised Balintore Formation. Apart from the basal Brora Roof Bed, the succession at Balintore does not lithologically resemble that at Brora, and the scheme of the Brora Argillaceous Formation, Brora Arenaceous Formation, and the Balintore Formation as previously defined is unworkable here. 
Keywords: lithostratigraphy; Jurassic; Bathonian; Callovian; Oxfordian; Scotland

\section{Introduction}

A near-complete Jurassic (Hettangian-Pliensbachian and Bathonian-Tithonian) siliciclasticdominated succession, at least 1100 m thick, crops out on the Moray Firth coast in north-east Scotland in four fault-bounded outliers in the Golspie-Brora-Helmsdale, Balintore, Ethie (or Eathie) and Lossiemouth areas (Fig. 1; Johnstone and Mykura, 1989; Andrews et al., 1990). This necessarily composite major succession is heterolithic, but exhibits significant lateral basin-wide coherence (Sykes, 1975; Andrews et al., 1990). The onshore succession represents the most westerly part of the Moray Firth Basin, which extends offshore into the North Sea where it is significantly thicker (Sunderland, 1972; Chesher and Lawson, 1983; Richards et al., 1993). Middle and Upper Jurassic strata are exceptionally well exposed on the foreshore between Brora and Helmsdale, and at Balintore (Figure 1; Riding, 2005; Barron et al., 2012). The occurrence at Ethie is of strata similar to Balintore in a skerry exposed only at low tide. The Lossiemouth outcrop is of Lower Jurassic strata.

Fig. 1. Structural features and distribution of Jurassic strata of the Moray Firth Basin. (Offshore is Hettangian to mid Oxfordian only. Based on Barron et al., 2012, fig.6, after Andrews, 1990, fig. 30).

Much of the existing Jurassic lithostratigraphical scheme of the Moray Firth Basin has been found to be unworkable. It includes certain outdated terminology, there is repeated use of certain place names and the formations have proved, in part, to be unmappable. Furthermore the successions at Brora and Balintore are significantly different, and hence merit independent lithostratigraphical schemes at formation as well as member levels.

The purpose of this contribution is to promulgate our recent proposals to revise the Jurassic lithostratigraphical nomenclature of the Moray Firth Basin (Barron et al., 2012). Specifically, (1) we propose the term Strathsteven Mudstone Formation for the mudstone-dominated, coarsening-upwards succession comprising the Brora Shale (including the Brora Roof Bed), Glauconitic Sandstone and Brora Brick Clay members of Sykes (1975) for the Brora area. (2) The Clynekirkton Sandstone Formation is proposed for the combined Fascally Siltstone, Fascally Sandstone, Clynelish Quarry Sandstone, Brora Sandstone and Ardassie Limestone members of Sykes (1975), and the overlying sandstone unit up to the base of the Helmsdale Boulder Beds, regarded as the Clynekirkton Sandstone Member of the Balintore Formation by Wright and Cox (2001, p. 192) but renamed and formally defined herein as the Achrimsdale Sandstone Member. This formation term was used on the recently published BGS maps of the area: Helmsdale (S 103E) and Golspie (S 103W) (British Geological Survey, 1998, 2002), where it proved mappable (Fig. 2), an essential criterion for viability. The formation is sandstone-dominated, and generally coarsens upwards. It is restricted to the Brora area. 
The much thinner Callovian-Oxfordian succession above the retained Brora Coal Formation at Balintore is considered herein to be best treated as a single formation. Hence, the Cadh'an-Righ Shale, Shandwick Clay, Shandwick Siltstone, Port-an-Righ Ironstone, and Port-anRigh Siltstone members together constitute the expanded Balintore Formation. The Brora Coal Formation is retained for both areas, and includes the well known Brora Coal seam. We consider this scheme (Table 1) to be pragmatic and workable.

\section{Fig. 2. Bedrock geological map of the Brora district.}

Contains Ordnance Survey data (C) Crown Copyright and Database rights 2013. Licence No. 100021290

Table 1. Lithostratigraphy of the Bathonian to Tithonian strata of the onshore Moray Firth.

\section{The history of the Middle and Upper Jurassic lithostratigraphy of the Moray Firth Basin}

The onshore outcrops of Jurassic strata in the Moray Firth Basin are small, and some of the units are poorly exposed. However their continuation into the significantly thicker offshore succession is well known due to the importance of the latter to the North Sea oil industry. Interest in the Jurassic geology of the Moray Firth stems from the discovery of coal at the end of the sixteenth century and its exploitation which continued intermittently into the late twentieth century (see Trewin and Hurst, 1993, p.33). Consequently the area was visited by many Victorian geologists, and early accounts include those of Murchison (1829b, a) and Judd (1873). After studies by Woodward (1905) and Macgregor and others (Macgregor et al., 1930), Geological Survey activity was led notably by Lee (1925; Lee and Pringle, 1932) who erected a large number of stratal names, unfortunately many bearing the geographical epithet 'Brora'.

With the emergence of the North Sea oil industry in the 1970s, research was renewed into the onshore strata that were deemed equivalent to offshore successions with reservoir potential. Lithostratigraphical schemes were published for the Bathonian by Hurst (1981) and the Callovian to Oxfordian by Sykes (1975), largely formalising the nomenclature of Lee (1925) but complying with modern practice in providing full definitions. Neves and Selley (1975) followed the scheme of Sykes (1975), and also described the underlying Lower and overlying Upper Jurassic successions. These lithostratigraphical schemes were summarised by Cope (1980, figs 6b, 9, 11b). The district was comprehensively described in an excursion guide by Trewin and Hurst (1993). Subsequently, the British Geological Survey (BGS) republished the two 1:50 000 scale maps, Helmsdale (S 103E) and Golspie (S 103W), that cover the Brora area (British Geological Survey, 1998, 2002), introducing three new formation names covering the entire Bathonian to Tithonian succession: the Brora Shale Formation, 
Clynekirkton Sandstone Formation and Helmsdale Boulder Beds Formation (including four new formalised members), without publishing any definitions. The Bathonian to Oxfordian strata of the onshore Moray Firth were described in detail by Wright and Cox (2001) and Cox and Sumbler (2002), without any lithostratigraphical revisions.

\section{The palaeogeography of the Moray Firth Basin}

The Moray Firth Basin was a region of substantial paralic to open marine siliciclastic deposition during the Jurassic; it was fringed by long-lived emergent areas that in part approximately coincide with modern land. Marginal and intrabasinal faulting (Fig. 1) was influential, and included features with substantial strike-slip sense (Andrews et al., 1990, pp. 8-13), for example it is thought that there was about $8 \mathrm{~km}$ of transcurrent movement on the Great Glen Fault between the Permian and the Cretaceous (McQuillan et al., 1982).

Through most of the Early Jurassic, the Moray Firth Basin formed part of the larger depositional area of the North Sea. However, from the late Toarcian through the Aalenian, Bajocian and early Bathonian, thermal uplift associated with vulcanicity formed a large plateau - the Mid North Sea High, severing the north-south marine connection. Aalenian to earliest Bathonian strata are unproven both on- and offshore in the basin. This apparent absence may simply be a result of non-exposure onshore, but offshore in the Inner Moray Firth an unconformity has been inferred, although in places there is evidence of continuous deposition from the Toarcian to the late Bathonian (Richards et al., 1993, p. 78).

Although the date of commencement is uncertain, subsequent deposition throughout the Moray Firth Basin was largely continuous, dominated at first by fluvial and paralic processes up to the late Bathonian, although the presence of shelly macrofaunas and microfaunas at some levels indicate brief marine incursions into coastal lagoons and swamps (Brora Coal Formation). The sea level rise commencing in the early Callovian brought prolonged marine deposition to the basin (Strathsteven Mudstone, Clynekirkton Sandstone, Balintore, Beatrice and Heather formations), initially to the western (including onshore) area, but then progressed eastwards. Full reconnection of the North Sea depositional areas may not have occurred until Late Jurassic (Oxfordian) times, with continued sea level rise and gradual subsidence of the Mid North Sea High. From the early Kimmeridgian onwards, the sediments preserved record deposition adjacent to an active submarine fault scarp - the Helmsdale Fault Zone - with a succession of mudstone, sandstone breccias and boulder beds displaying rapid vertical and lateral lithological passages (there is some evidence from the Dunrobin Bay Formation that the fault may have also been active in the early Jurassic). The lateral variability in the Kimmeridgian to Tithonian (Bolonian-lowest Tithonian) succession precludes some inferences about superposition, although the succession includes sufficient ammonite-bearing strata to indicate generally south-west to north-east-younging. The Kintradwell Boulder Beds and Allt na Cuile Sandstone formations are inferred to be approximately coeval, overlain by the Helmsdale Boulder Beds Formation (Wignall and Pickering, 1993). 


\section{The scope and definition of the Sutherland Group}

In formalising the onshore Middle Jurassic succession of the Moray Firth Basin, neither Sykes (1975) nor Hurst (1981) assigned their formations to a group. Simms et al. (2004, p. 310) implicitly included the Lower Jurassic Dunrobin Bay Formation in the Lias Group of England. A considerably revised scheme of formations within a formal group structure is proposed here (see section 5). Richard A. Smith of BGS erected a 'Sutherland Group' for BGS digital map data in 2000 which included the entire Jurassic succession, ranging down possibly into the uppermost Triassic, but a formal definition remained unpublished. The Sutherland Group appeared on the BGS Stratigraphical Chart for northern Britain (Waters et al., 2007), despite usage by Simms et al. (2004) of the Lias Group in this region. A revised definition of the Sutherland Group, based on the original concept of R.A. Smith, is proposed herein, to encompass the succession from the onshore Dunrobin Bay Formation (?Hettangian to Pliensbachian) to the Helmsdale Boulder Beds Formation (Kimmeridgian to lowest Portlandian). The youngest beds were assigned to the earliest Portlandian (Albani Zone) by Barron (1989). Despite the conspicuously heterolithic nature of this succession, it possesses considerable coherence, consisting of paralic to marine siliciclastic sediments. Deposition is inferred to have been essentially continuous, but Toarcian to Bajocian strata have not been positively identified.

\subsection{SUTHERLAND GROUP}

Name. Named after the former county of Sutherland in north-east Scotland, formally proposed herein.

Type section. Coastal section, at high water mark from Dunrobin Pier $2 \mathrm{~km}$ ENE of Golspie to Ord Point $4 \mathrm{~km}$ ENE of Helmsdale, a distance of $27 \mathrm{~km}$. Exposes highly discontinuous section including incomplete Dunrobin Bay, Brora Coal, Strathsteven Mudstone, Clynekirkton Sandstone and Helmsdale Boulder Beds formations [NC 851005 - ND 062 175] (Sykes, 1975; Hurst, 1981; Batten et al., 1986; Wright and Cox, 2001)

Type area. Onshore Moray Firth coastal area.

Reference section(s). Lossiemouth No. 4 Borehole (NJ26NW4) [NJ 2157 6985] from 12.8 m to $82.3 \mathrm{~m}$ (terminal depth). Sequence of sandstone and mudstone, calcareous in part, thought to be all Sinemurian (Berridge and Ivimey-Cook, 1967). 
Table 2. Formal subdivisions of the Sutherland Group (approximately descending order)

\begin{tabular}{|l|}
\hline Helmsdale Boulder Beds Formation (Lee, 1925) \\
\hline $\begin{array}{l}\text { Allt na Cuile Sandstone Formation (Neves and Selley, 1975; Brookfield, } \\
\text { 1976; Pickering, 1984; Wignall and Pickering, 1993; Wright and Cox, } \\
\text { 2001, p194) }\end{array}$ \\
\hline Kintradwell Boulder Beds Formation (Pickering, 1984) \\
\hline Clynekirkton Sandstone Formation, defined herein \\
\hline Strathsteven Mudstone Formation, defined herein \\
\hline $\begin{array}{l}\text { Balintore Formation, defined herein: lateral equivalent of the } \\
\text { Strathsteven Mudstone Formation and much of the Clynekirkton } \\
\text { Sandstone Formation }\end{array}$ \\
\hline Brora Coal Formation (Neves and Selley, 1975) \\
\hline Dunrobin Bay Formation* (Batten et al., 1986) \\
\hline
\end{tabular}

* entirely Lower Jurassic. The Dunrobin Bay Group of Richards et al. (1993) is the approximately equivalent unit in the offshore Inner Moray Firth, but is not included in the Sutherland Group.

Lithology. Sequence of predominantly mudstone, siltstone and sandstone, with common shelly fauna at many levels, variously calcareous, carbonaceous, bituminous, with thin sandy limestone beds, ironstone beds, thin coal seams, a basal conglomerate and boulder beds towards the top.

Lithogenetic description. Generally shallow marine with periodic and significant terrigenous sediment input and transient paralic conditions. Significant fault-influenced near-shore coarse clastic deposition in late Jurassic times.

Landform description. None

Definition of upper boundary. Top of the interbedded boulder beds, sandstone and mudstone beds of the Helmsdale Boulder Beds Formation, not at outcrop onshore. Overlying bedrock formation is unknown.

Definition of lower boundary. Unconformity: nodular carbonate rock of the Stotfield Cherty Rock Formation (Triassic) overlain by interbedded conglomerate and sandstone of the Dunrobin Pier Conglomerate Member of the Dunrobin Bay Formation

Thickness. At least $1400 \mathrm{~m}$.

Distribution. Coastal strips of Moray Firth, north-east Scotland, from Golspie to Helmsdale, near Balintore, near Lossiemouth. Correlates offshore in the Inner Moray Firth with the 6 
combined Dunrobin Bay and Fladen groups and the Heather and Kimmeridge Clay

formations (Hudson and Trewin, 2002, fig. 11.7)

Previous names. None.

Age. ?Hettangian to Tithonian (lowest Portlandian).

\section{Revised formational framework}

The current review of the lithostratigraphy of the region has identified a number of problems:

- The same place name (i.e. 'Brora') appears in the names of three adjacent formations (the place name also appears in the names of a number of the minor units), against the recommendations of current stratigraphical procedure (Rawson et al., 2002, p. 6).

- The terms ‘argillaceous’ and ‘arenaceous’ are outmoded.

- In republishing the geological maps of the Brora area, BGS found that the mapped boundaries did not coincide with the formations of Sykes (1975) and erected a new scheme. However, this ignored a formation (Brora Coal) that is mappable onshore and recognised offshore.

- At Balintore, the Brora Argillaceous, Brora Arenaceous, and old Balintore formations are not satisfactory. For example the boundary between the Brora Argillaceous and Brora Arenaceous formations lies within a sequence of sandy siltstone.

- The successions at Brora and Balintore (now over $30 \mathrm{~km}$ apart) are significantly different, each comprising several satisfactory locally-defined members. Generally, above the Brora Coal Formation they cannot be directly correlated. The only Callovian-Oxfordian unit recognised in both areas is the Brora Roof Bed.

In view of the above, we propose that:

- The Brora Coal Formation is retained, and includes the well known Brora Coal seam. We include its formal definition (subsection 5.1.1) for completeness.

- The Brora Shale (including the Brora Roof Bed), Glauconitic Sandstone and Brora Brick Clay members, all of Sykes (1975), constitute the new Strathsteven Mudstone Formation (Barron et al., 2012). This is a mudstone-dominated, generally coarsening-upwards succession. Its base was proved in a coal shaft at Strathsteven, which place name is unused in other stratigraphical terms. It is restricted to the Brora area.

- The Clynekirkton Sandstone Formation (Barron et al., 2012) is proposed for the combined Fascally Siltstone, Fascally Sandstone, Clynelish Quarry Sandstone, Brora Sandstone and Ardassie Limestone members of Sykes (1975), and the overlying sandstone unit up to the base of the Helmsdale Boulder Beds, regarded as the 
Clynekirkton Sandstone Member of the Balintore Formation by Wright and Cox (2001, p. 192) but renamed herein as the Achrimsdale Sandstone Member. This formation term was used on the recently published BGS maps of the area: Helmsdale (S 103E) and Golspie (S 103W) (British Geological Survey, 1998, 2002). We considered proposing a new formation name with a different geographical epithet, but we regard the name published in 1998 by BGS as preferable to the usage of Wright and Cox (2001). The formation is sandstone-dominated, and generally coarsens upwards. It is restricted to the Brora area.

- The much thinner Callovian-Oxfordian succession above the retained Brora Coal Formation at Balintore should be in a single formation. Hence, the Cadh'-an-Righ, Shandwick Clay, Shandwick Siltstone, Port-an-Righ Ironstone, and Port-an-Righ Siltstone members together constitute the (expanded) Balintore Formation (Barron et al., 2012).

We accept the three Kimmeridgian to Tithonian (lowest Portlandian) units - the Kintradwell Boulder Beds, Allt na Cuile Sandstone Formation and Helmsdale Boulder Beds (Pickering, 1984; Wignall and Pickering, 1993; Wright and Cox, 2001) - as formal formations of the Sutherland Group. The boundaries between the Middle and Upper Jurassic formations in the Brora area have proved mappable (Fig. 2), and the Brora Coal Formation-Balintore Formation contact at Balintore was formerly visible on the foreshore. Thus we consider this scheme (Table 1) to be pragmatic and workable.

\subsection{BRORA DISTRICT FORMATIONS}

\subsubsection{Brora Coal Formation}

Name. Named as formal formation after the town of Brora, Sutherland by Neves and Selley (1975).

Type section. Foreshore south of the River Brora estuary, Sutherland, between the Brora Fault the railway and the sea (Hurst, 1981, fig. 1). The Brora Coal Formation on the foreshore has subdued relief, is submerged at high tide and is partially covered by erratic boulders. However it is fully exposed and the top of the formation is easily located because the immediately overlying Brora Roof Bed forms prominent outcrops on the foreshore. Hurst (1981, fig. 1) illustrated four W-E transects through the formation in the type area, [NC 900 030] (Neves and Selley, 1975; Hurst, 1981).

Type area. Brora area, Sutherland, Scotland.

Table 3. Formal subdivisions of the Brora Coal Formation

Brora Coal Bed

Inverbrora Member (Hurst, 1981)

Doll Member (Hurst, 1981) 
Lithology. Sandstone, medium-grained, white, soft, pure quartz, massive and cross-bedded, cross-laminated and parallel laminated, up to $20 \mathrm{~m}$ thick (Doll Sandstone Unit (= Bed) of Hurst (1981), overlain by over $30 \mathrm{~m}$ of grey shaly mudstone with thin interbedded sideritic mudstone beds ('cementstones' of early usage) that are laterally extensive; together these two units constitute the Doll Member. Its top is marked by a prominent brecciated sideritecemented mudstone horizon (Bed 1 of Hurst, 1981). Overlying Bed 1 are about $15 \mathrm{~m}$ of grey and black, laminated, bituminous fissile mudstones, some of which approach oil shale composition. Two coals are developed in this succession (the Inverbrora Member), including a thin coal developed about $8 \mathrm{~m}$ below the top of the formation and a prominent seam, $1 \mathrm{~m}$ thick, forming the uppermost bed and termed the Brora Coal (Bed). Biota is relatively sparse and comprises bivalves, plant debris and fish scales. Two bivalve-rich beds, largely composed of Isognomon and Neomiodon, are present between 3 and $4 \mathrm{~m}$ below the top of the formation and these beds were interpreted as a maximum flooding surface by Stephen and Davies (1998).

Lithogenetic description. The Doll Member was interpreted as representing an alluvial plain by Hurst (1981). The overlying Inverbrora Member was considered to represent a phase of fluvial abandonment, stagnating into a delta swamp (Hurst, 1981) with a stratified water column and anoxic bottom conditions. The presence of Isognomon represents the first indications of sporadic marine influence in this unit (Hudson, 1962). The intermittently marine nature of the uppermost part of the formation was confirmed by the presence of marine palynomorphs (MacLennan and Trewin, 1989; Riding, 2005). The drifted Brora Coal (Bed) represents a phase of clastic starvation, and its top was interpreted as a combined transgressive surface/sequence boundary by Stephen and Davies (1998).

Landform description. The formation, including the Doll Member has subdued relief.

Definition of upper boundary. Onshore, the boundary with the overlying unit is sharp and planar and although apparently conformable is probably erosional. The Brora Coal is overlain by the transgressive, intensely bioturbated medium-grained sandstone of the Brora Roof Bed, which is the lowermost bed of the Brora Shale Member (Strathsteven Mudstone Formation) at Brora, or of the Cadh'-an-Righ Shale Member (Balintore Formation) at Balintore.

Offshore, the boundary with the overlying Beatrice Formation is a sharp, planar junction between a coal-bearing mudstone or coal, which is equivalent to the Brora Coal (Bed), and the fine- to medium-grained sandstones of the Beatrice Formation (Richards et al., 1993, p. 78).

Definition of lower boundary. The base of the Brora Coal Formation is not exposed onshore. The putative contact is thought to be a sharp unconformable contact between the grey mudstones of the Lady's Walk Shale Member (Dunrobin Bay Formation; Lower Jurassic, Hettangian to Pliensbachian) and the white medium sandstone of the Doll Sandstone Unit of the Doll Member. 
Offshore in the Great Glen Sub-Basin in the western part of the Inner Moray Firth, the Brora Coal Formation overlies the Orrin Formation (Barron et al., 2012, table 10). Richards et al. (1993, p. 79) illustrated the boundary between the fine- to medium-grained sandstones of the Orrin Formation, and the interbedded sandstones and mudstones of the Brora Coal Formation as unconformable. However, in well $11 / 25-1$, this boundary is gradational and is marked by a transitional passage from the massive sandstones of the Orrin Formation to the interbedded mudstones and sandstones with sporadic coaly horizons of the Brora Coal Formation (Richards et al., 1993, p. 78). Further offshore the Brora Coal Formation is partially or entirely absent due to erosion (Andrews et al., 1990, figs. 27, 28), and in some wells the Brora Coal (Bed) directly overlies the Orrin Formation (Richards et al., 1993, panel 8).

Thickness. Onshore, at the type section, Hurst (1981) reported a thickness of at least $65 \mathrm{~m}$. This contrasts with at least $31.5 \mathrm{~m}$ reported by Neves and Selley (1975). A significant part of the Doll Member forms approximately half the thickness of the section at a foreshore outcrop [NC 893 025] 400 m north-east of Sputie Burn (Hurst, 1981, p. 174). South of Brora at Balintore [NH 851 728], the Brora Coal Bed is significantly thinner than at Brora, where it is only $20 \mathrm{~cm}$ thick. The total thickness of the underlying Brora Coal Formation at Balintore is unknown because the base is not exposed. Approximately $3 \mathrm{~m}$ of the Inverbrora Member have been observed and Judd (1873, pp 162-163) reported at least 36 feet (10 m).

Offshore, in the western part of the Inner Moray Firth Basin, the Brora Coal Formation is significantly thicker than observed onshore; for example, in offshore wells 11/25-1, 11/30a-9 and 12/21-3, it is 116, 183 and 113 m thick respectively (Richards et al., 1993, p.79).

Distribution. The Brora Coal Formation is confined to the Moray Firth area, north-east Scotland. Onshore, it forms an outcrop, bounded to the north-west by a fault, along a coastal strip from the type section [NC 900 030], south of the River Brora estuary, and further southwest along the foreshore, to a point [NC 893 025) 400 m north of Sputie Burn (Hurst, 1981, fig. 1), and is thought to continue at depth through to Strathsteven [NC 88 01]. It is also at depth north-west of the fault in the Brora area. It crops out on the foreshore south of Balintore [NH 849723 to 857 739]. This is a narrow sliver, between the Great Glen Fault Zone offshore to the east and a parallel fault in the cliffs to the west (Riding, 2005, fig. 1).

Offshore it is present in the western part of the Inner Moray Firth Basin, where it thins rapidly toward the east (Andrews et al., 1990, figs. 27, 28).

Previous names. Estuarine Series of Lee (1925)

Age. Bathonian to early Callovian. See also Richards et al. (1993).

\subsubsection{Strathsteven Mudstone Formation}

Name. Formerly part of the Brora Argillaceous Formation (Brora Roof Bed to Brora Brick Clay Member at Brora) of Sykes (1975). Defined herein to include the members as listed in Table 4, and by Barron et al. (2012). Named after Strathsteven village on the Moray Firth coast near Brora. 
Type section. The type section is a composite of the foreshore south of the River Brora estuary and the cliffs of the River Brora. The type section of the Brora Shale Member is the foreshore [NC 904 031] south of the River Brora estuary, to the east of Inverbrora Farm [NC 893 034]. The stratotype of the Glauconitic Sandstone Member is in the cliffs in the north bank of the River Brora [NC 889 040]. The type sections of the Brora Brick Clay Member are at the west end of cliffs of the River Brora [NC 887 038], and on the foreshore [NC 907032 ] south of the mouth of the River Brora, (Sykes, 1975, as modified herein; Trewin and Hurst, 1993; British Geological Survey, 1998).

Type area. Brora area, Sutherland, Scotland.

Reference section(s). Brick pit section [NC 897 040] near the village of Brora, exposes middle to upper part of the Brora Brick Clay Member, (Sykes, 1975). Shaft for coal [NC 8831 0185] at Strathsteven exposes Brora Roof Bed near the surface, overlying Brora Coal (Lee, 1925, p.79).

\section{Table 4. Formal subdivisions of the Strathsteven Mudstone Formation}

Brora Brick Clay Member (Arkell, 1933; Sykes, 1975).

Glauconitic Sandstone Member (Sykes, 1975).

Brora Shale Member (Arkell, 1933; Sykes, 1975), including Brora Roof

Bed.

Lithology. Mudstone and siltstone, generally bituminous with significant subordinate units of silty sandstone, commonly muddy and glauconitic. At Brora, the overall thickness is about $55 \mathrm{~m}$. The lowermost unit is the Brora Roof Bed - up to $2.3 \mathrm{~m}$ of bioturbated, shelly mediumgrained sandstone with scattered quartzite pebbles and coal fragments. It is overlain by about $2.3 \mathrm{~m}$ of silty sand grading up into about $25 \mathrm{~m}$ of bituminous fissile mudstone with thin interbedded glauconitic sandstone beds. This is the Brora Shale Bed that, together with the Brora Roof Bed, makes up the Brora Shale Member (Arkell, 1933; Sykes, 1975). This is overlain by $10.1 \mathrm{~m}$ of coarsening-upwards glauconitic muddy and silty sandstones with a siltstone interbed - the Glauconitic Sandstone Member (Sykes, 1975), overlain by $15 \mathrm{~m}$ of bituminous sandy siltstone with mudstone intercalations; five fining-upwards cycles have been recognised - the Brora Brick Clay Member (Arkell, 1933; Sykes, 1975). The formation yields marine biota and marine microfossils throughout. The macrofauna is dominated by ammonites, belemnites, bivalves, brachiopods and gastropods (Sykes, 1975; Cox and Sumbler, 2002, p. 374), and dinoflagellate cysts are abundant and diverse (Riding, 2005). The sequence stratigraphy of the formation was interpreted by Stephen and Davies (1998).

Lithogenetic description. Persistent open marine deposition with some phases of mild seabed anoxia represented by the bituminous mudstone.

Landform description. Unknown. 
Definition of upper boundary. The upper boundary is defined by a change up from the bituminous sandy siltstone with mudstone intercalations of the Brora Brick Clay Member to the coarse siltstone to silty fine-grained sandstone of the Fascally Siltstone Member of the Clynekirkton Sandstone Formation. The boundary is conformable.

Definition of lower boundary. The formation overlies the Brora Coal (Bed) of the Brora Coal Formation. The boundary is marked by a sharp planar lithological change where bioturbated medium-grained sandstone (the Brora Roof Bed) rests on the Brora Coal. The boundary appears to be erosional.

Thickness. At the type section at Brora, the thickness of the formation is about $55 \mathrm{~m}$.

Distribution. The Strathsteven Mudstone Formation is confined to the onshore Moray Firth area, north-east Scotland. It is present in the coastal strip around Brora, up to the BroraHelmsdale Fault, at outcrop and at depth. It correlates offshore in the Inner Moray Firth with the lower part of the Beatrice Formation of the Fladen Group (Richards et al., 1993)

Previous names. Part of Brora Argillaceous Series of Lee and Pringle (1932, p. 202). Part of Brora Argillaceous Formation of Sykes (1975).

Age. Callovian: Koenigi Zone to Athleta Zone.

\subsubsection{Clynekirkton Sandstone Formation}

Name. A new formation published on BGS maps of the area (British Geological Survey, 1998, 2002), and defined herein to include the members as listed in Table 5. Named after a settlement north of Brora which is now shown as West Clyne and East Clyne on Ordnance Survey maps. See also Barron et al. (2012)

Type section. The type section of the Clynekirkton Sandstone Formation is a composite one in the foreshore south of Brora and in cliff sections on the south bank of the River Brora. The foreshore [NC 909 031] south of the River Brora estuary includes the type section of the Fascally Siltstone Member (Sykes, 1975). The type section of the Fascally Sandstone Member is on the north bank of the River Brora [NC 899 040]. The Clynelish Quarry Sandstone Member was named after Clynelish Quarry [NC 893 045], however the stratotype is in cliffs on the south bank of the River Brora: the lower part is $800 \mathrm{~m} \mathrm{WSW}$ of the A9 road bridge [NC 898 038] and the upper part is $250 \mathrm{~m}$ downstream opposite the disused Brora colliery [NC 899 039] (Trewin and Hurst, 1993, localities 4 and 5, with amendments; Cox and Sumbler, 2002).

The type section of the Brora Sandstone Member is composite. The majority of the section is in the cliffs on the south bank of the River Brora [NC 905 039], with the uppermost beds exposed south of Ardassie Point. The base of the section is $540 \mathrm{~m}$ west of the A9 road bridge, running eastwards to the fault, $140 \mathrm{~m}$ east of the bridge. From the fault, there is a gap in the exposure until the uppermost beds are seen on the foreshore south of Ardassie Point [NC 911 038 to 913 041] overlain here by the Ardassie Limestone Member at its type section. There is no type section for the Achrimsdale Sandstone Member but it was reported exposed near 
Clynekirkton (Clyne) church [NC 8940 0616] by Lee (1925, pp 96, 99). See also Trewin and Hurst (1993) and Wright and Cox (2001).

Type area. Brora area, Sutherland, Scotland.

Reference section(s). None.

Table 5. Formal subdivisions of the Clynekirkton Sandstone Formation

\begin{tabular}{|l|}
\hline Achrimsdale Sandstone Member, defined herein \\
\hline Ardassie Limestone Member (Sykes, 1975). \\
\hline Brora Sandstone Member (Sykes, 1975). \\
\hline Clynelish Quarry Sandstone Member (Sykes, 1975). \\
\hline Fascally Sandstone Member (Sykes, 1975). \\
\hline Fascally Siltstone Member (Sykes, 1975). \\
\hline
\end{tabular}

Lithology. Sandstone, variably cemented, sandy siltstone, and sand. Some carbonaceous or calcareous beds and minor amounts of sandy limestone. Lower part has a rich marine shelly fauna. At Brora, the overall thickness is at least $500 \mathrm{~m}$. The lowermost Fascally Siltstone Member comprises $33.5 \mathrm{~m}$ of coarse siltstone, passing upwards into silty, fine-grained sandstone. It is overlain by $6.5 \mathrm{~m}$ of intensely bioturbated fine-grained muddy sandstone in several fining-upward cycles, rich in ammonites and bivalves, the Fascally Sandstone Member, that culminate in a massive sandy siltstone. Above are about $20 \mathrm{~m}$ of friable, finegrained yellow sand with occasional carbonaceous debris, forming the Clynelish Quarry Sandstone Member, in which cemented sandstone with horizons of nodular silicified sandstone, flame structures and a rich fauna of ammonites and bivalves is locally seen. The overlying Brora Sandstone Member is at least $30 \mathrm{~m}$ of fine-grained friable sandstone with trough cross bedding and some lenticular quartz conglomerates. This is overlain by the Ardassie Limestone Member comprising at least $12 \mathrm{~m}$ of interbedded muddy carbonaceous sandstone and sandy limestone beds 0.3 to $1.1 \mathrm{~m}$ thick. Younger strata present north of Brora, up to the base of the Kintradwell Boulder Beds and Allt na Cuile Sandstone formations are inferred by BGS (1998) to comprise about $400 \mathrm{~m}$ of pale grey, calcareous and silicacemented sandstones with rare pebbles and subordinate shelly siltstones and mudstones or carbonaceous beds (Lee, 1925). These beds are not well known at outcrop and have been assigned to the Clynekirkton Sandstone Formation by BGS (1998), but there was no formal description given, nor type/reference sections proposed. They were regarded as the Clynekirkton Sandstone Member of the Balintore Formation by Wright and Cox (2001, p. 192), but are renamed herein the Achrimsdale Sandstone Member to avoid confusion with its parent formation (see section 5.1.3.1). 
The formation yields marine biota and microfossils throughout the beds up to the top of the Ardassie Limestone, and some indications of marine origin from the Achrimsdale Sandstone (section 5.1.3.1). The macrofauna is dominated by ammonites and bivalves; dinoflagellate cysts are abundant in the Fascally Sandstone Member (Riding, 2005). The beds overlying the Ardassie Limestone are of inferred mid and late Oxfordian (possibly earliest Kimmeridgian) age. The sequence stratigraphy of this formation was interpreted by Stephen and Davies (1998).

Lithogenetic description. The formation represents shallow open marine deposition with substantial periodic terrigenous sediment and organic material input from nearby land areas to the west.

Landform description. Unknown.

Definition of upper boundary. Change up (not exposed) from sandstone to matrix-supported conglomerate of cobbles and boulders of sandstone, interbedded with laminated siltstone and sandstone (Kintradwell Boulder Beds Formation, and Allt na Cuile Sandstone Formation) (Wright and Cox, 2001, fig. 5.2)

Definition of lower boundary. The lower boundary is defined by a change up from the bituminous sandy siltstone with mudstone intercalations of the Brora Brick Clay Member of the Strathsteven Mudstone Formation to the coarse siltstone to silty fine-grained sandstone of the Fascally Siltstone Member. The boundary is conformable.

Thickness. At the composite type section at Brora, the aggregated thickness of the exposed, lower part of the formation is at least $102 \mathrm{~m}$, with an estimated additional $400 \mathrm{~m}$ of unexposed strata above.

Distribution. The Clynekirkton Sandstone Formation is confined to the onshore area around Brora, on the Moray Firth, north-east Scotland. It is exposed on the foreshore around the River Brora estuary and in the cliffs bordering the River Brora. Its outcrop extends inland up to the Brora-Helmsdale Fault. It correlates offshore in the Inner Moray Firth with the upper part of the Beatrice Formation of the Fladen Group, plus at least part of the Heather Formation of the Humber Group (Richards et al., 1993).

Previous names. Upper part (Fascally Siltstone Member) of Brora Argillaceous Formation (= Series of Lee, 1925, p.86), plus Brora Arenaceous Formation (= Series of Lee and Pringle, 1932, p.202), plus overlying Ardassie Limestone Member of Balintore Formation, all of Sykes (1975). This unit was considered to be a member of the Balintore Formation of Sykes (1975) by Wright and Cox (2001).

Age. Callovian-Kimmeridgian. 


\subsubsection{Achrimsdale Sandstone Member}

Name. Renaming of the Clynekirkton Sandstone Member of Wright and Cox (2001, p. 192), to avoid confusion with its parent formation. Named after a settlement north of Brora [NC907 066].

Type section. There is no type section for the Achrimsdale Sandstone Member but beds of sandstone, sandy mudstone and carbonaceous mudstone were reported exposed in the stream bank upstream from Clyne (Clynekirkton) church [NC 8940 0616] by Lee (1925, pp 96, 99).

Type area. Brora area, Sutherland, Scotland.

Reference section(s). Foreshore at Lothbeg [NC 946 095] exposes bioturbated sandstone and mudstone near the top of the member, although the top is not exposed (Trewin and Hurst, 1993, pp 91-94).

Lithology. Sandstone, pale grey, calcareous and silica-cemented, bioturbated, with rare pebbles and subordinate mudstones and shelly siltstones. Mudstones may include resinous lignite and coaly beds and the siltstone beds locally contain scattered carbonaceous fragments and microcrystalline limestone nodules (Lee, 1925, p. 99; Trewin and Hurst, 1993, pp 91-94; British Geological Survey, 1998). Lee (1925, p. 99) reports the find of a cast of a crinoid stem. BGS field data (1891 and 1923) mentions “oolitic sand” seen in stream beds on the outcrop and worm tubes in carbonaceous sandy mudstone and muddy sandstone on the foreshore.

Lithogenetic description. The formation represents shallow open marine deposition with substantial periodic terrigenous sediment input from nearby land areas to the west.

Landform description. Unknown.

Definition of upper boundary. Change up (not exposed) from sandstone to matrix-supported conglomerate of cobbles and boulders of sandstone, interbedded with laminated siltstone and sandstone (Kintradwell Boulder Beds Member of the Helmsdale Boulder Beds Formation, and Allt na Cuile Sandstone [Formation]) (Wright and Cox, 2001, fig. 5.2)

Definition of lower boundary. The lower boundary is defined by a change up from the interbedded muddy carbonaceous sandstone and sandy limestone beds of the Ardassie Limestone Member to the sandstone and mudstone of the Achrimsdale Sandstone Member. The nature of the boundary is unknown but is inferred to be conformable.

Thickness. Estimated 400 m.

Distribution. The Achrimsdale Sandstone Member is confined to the onshore area north of Brora, on the Moray Firth, north-east Scotland. Its outcrop extends inland up to the BroraHelmsdale Fault.

Previous names. Clynekirkton Sandstone Member of Wright and Cox (2001).

Age. Mid to late Oxfordian to early Kimmeridgian is inferred. 


\subsection{BALINTORE DISTRICT FORMATIONS}

\subsubsection{Brora Coal Formation}

See Section 5.1.1.

\subsubsection{Balintore Formation}

Name. Substantial redefinition herein of Sykes (1975, p. 58, 59, 60-62). See also Barron et al. (2012). Named after Balintore village on Moray Firth coast.

Type section. The type section of the Balintore Formation is entirely on the foreshore at Cadh'-an-Righ and Port-an-Righ [NH 849723 to 853 733]. This exposes the formation continuously from the base upwards to the uppermost beds seen before they dip into the sea (Sykes, 1975; Wright and Cox, 2001, pp. 188-190; Cox and Sumbler, 2002, pp. 376-379).

Type area. Balintore area, Ross and Cromarty, Scotland.

Reference section(s). Bow Buoy Skerry [NH 7696 6214], near Eathie, Ross and Cromarty. Exposes, only at low tide, about $30 \mathrm{~m}$ of shelly bioturbated very fine-grained sandstone beds, dipping at $70^{\circ}$ to south-east, base and top of formation not exposed.

Table 6. Formal subdivisions of the Balintore Formation

Port-an-Righ Siltstone Member (Arkell, 1933; Sykes, 1975).

Port-an-Righ Ironstone Member (Buckman, 1923; Sykes, 1975)

Shandwick Siltstone Member (Arkell, 1933; Sykes, 1975).

Shandwick Clay Member (Sykes, 1975).

Cadh’-an-Righ Shale Member (Sykes, 1975)

Lithology. The Balintore Formation is dominated by moderately to richly fossiliferous sandstone, sand and sandy siltstone (variously calcareous or glauconitic), and mudstone, bituminous in parts. The formation is about $68 \mathrm{~m}$ thick at Balintore. The lowermost unit, the Cadh'-an-Righ Shale Member, is $4.2 \mathrm{~m}$ of sparsely fossiliferous bituminous fissile mudstone, with interbedded thin glauconitic siltstone, and includes the 0.5 m-thick bioturbated sandstone of the Brora Roof Bed at the base. The overlying Shandwick Clay Member is about $28 \mathrm{~m}$ thick: the lower $24 \mathrm{~m}$ are bioturbated grey-green clay with layers of limestone nodules at the base, and the uppermost $4.1 \mathrm{~m}$ comprises sandy siltstone. Above is the Shandwick Siltstone Member - $12.1 \mathrm{~m}$ of fossiliferous siltstone, with alternating beds that are more or less calcareous. Overlying it is the Port-an-Righ Ironstone Member (Buckman, 1923) comprising $2.2 \mathrm{~m}$ of muddy, glauconitic sand with interbedded bands of red-weathering nodular glauconitic limestone, all rich in ammonites. The overlying Port-an-Righ Siltstone Member is $21.7 \mathrm{~m}$ thick, and largely consists of relatively sparsely fossiliferous bituminous coarse silt. This unit comprises thin (0.1 to $1.8 \mathrm{~m})$ rhythmic units that coarsen upwards from 
carbonaceous shale or silt, to fine-grained muddy sandstone. The uppermost bed is $5.7 \mathrm{~m}$ of fine-grained muddy sandstone. There is strong evidence that there are fine-grained beds above the Port-an-Righ Siltstone Member that are not exposed onshore. The Balintore Formation yields marine biota and marine microfossils throughout. The macrofauna is dominated by ammonites and bivalves, with belemnites, brachiopods and gastropods, and dinoflagellate cysts are generally abundant and diverse (Riding, 2005).

Lithogenetic description. The Balintore Formation represents consistent open marine deposition with some phases of mild seabed anoxia represented by the bituminous shale.

Landform description. The lithologically contrasting beds result in prominent ridges at some levels in the foreshore outcrops.

Definition of upper boundary. The upper boundary of the Balintore Formation at Balintore is not exposed. The Port-an-Righ Siltstone Member is the youngest unit seen, and the uppermost beds dip off into deep water at low tide. Limestone nodules with Early Oxfordian ammonites are found on the foreshore, and Sykes (1975, p. 62) inferred the probable presence of a relatively soft, claystone-dominated succession. It may be present in offshore boreholes (MacLennan and Trewin, 1989).

Definition of lower boundary. The lower boundary is a sharp non-sequential change up from the Brora Coal (Bed) of the Brora Coal Formation to bioturbated medium-grained sandstone of the Brora Roof Bed of the Cadh'-an-Righ Shale Member (MacLennan and Trewin, 1989)

Thickness. At the type section at Balintore, the thickness of this formation is about $68 \mathrm{~m}$ although the top is unseen. At Bow Buoy Skerry, about $30 \mathrm{~m}$ of strata are exposed, base and top unseen.

Distribution. The Balintore Formation is confined to the onshore Moray Firth area, north-east Scotland, forming a narrow strip along the coast at Port-an-Righ, Balintore, and an outcrop exposed only at low tide near Eathie. Both are bounded to the west by a fault parallel to the Great Glen Fault Zone, which lies close offshore to the east. It correlates offshore in the Inner Moray Firth with the lower part of the Beatrice Formation of the Fladen Group (Richards et al., 1993)

Previous names. Brora Argillaceous Formation plus Brora Arenaceous Formation plus Balintore Formation (at Balintore) of Sykes (1975).

Age. Callovian-Oxfordian: Koenigi Zone to Tenuiserratum Zone or younger.

\section{Discussion}

The existing Bathonian to Oxfordian lithostratigraphical schemes at Brora and Balintore in the onshore Moray Firth Basin use the same formation names in both areas, despite significant differences. Three of the present formation names include the same place name (i.e. 'Brora'), and use outdated lithologies; both of these are contrary to recommended 
stratigraphical practice (Rawson et al., 2002, p. 6). Therefore, the Brora Argillaceous, Brora Arenaceous and Balintore formations at Brora are not fit for purpose and we propose a new Strathsteven Mudstone Formation and a redefined Clynekirkton Sandstone Formation. The Brora Coal Formation is recognisable throughout the basin, and is retained as currently defined.

We reviewed the definitions of the constituent members, and concluded that they were all coherent stratigraphical units. The duplication of geographical names in the nomenclature of the members is unfortunate, and alternative names were considered. However in the interests of nomenclatorial stability, all except one were retained. We include a full definition of the Achrimsdale Sandstone Member.

The above formational scheme for the Moray Firth represents a significant improvement over that of Sykes (1975), which largely retained the units and terminology of Lee and Pringle (1932, p. 202). It establishes units that from the enclosed definitions can be distinguished on the ground and represented on maps.

\section{Acknowledgements}

The authors consulted widely regarding this new lithostratigraphical scheme in order to gauge reactions and as a result we consider that we have reached a consensus. We gratefully acknowledge advice from the late Dr Robert W.O’B Knox (1942-2013), to whom this paper is dedicated. We publish with the approval of the Executive Director, British Geological Survey (NERC).

\section{References}

Andrews, I.J., Long, D., Richards, P.C., Thomson, A.R., Brown, S., Chesher, J.A., McCormac, M., 1990. The geology of the Moray Firth. British Geological Survey, London. Arkell, W.J., 1933. The Jurassic System in Great Britain. Clarendon Press, Oxford. Barron, A.J.M., Lott, G.K., Riding, J.B., 2012. Stratigraphical framework for the Middle Jurassic strata of Great Britain and the adjoining continental shelf, British Geological Survey Research Report RR/11/06.

Barron, H.F., 1989. Dinoflagellate cyst biostratigraphy and palaeoenvironments of the Upper Jurassic (Kimmeridgian to basal Portlandian) of the Helmsdale region, east Sutherland, Scotland, In: Batten, D.J., Keen, M.C. (Eds.), Northwest European Micropalaeontology and Palynology. British Micropalaeontological Society Series. Ellis Horwood Limited, Chichester, pp. 193-213.

Batten, D.J., Trewin, N.H., Tudhope, A.W., 1986. The Triassic-Jurassic junction at Golspie, Inner Moray Firth Basin. Scottish Journal of Geology 22, 85-98.

Berridge, N.G., Ivimey-Cook, H.C., 1967. The geology of a Geological Survey borehole at Lossiemouth, Morayshire. Bulletin of the Geological Survey of Great Britain 27, 155-169. British Geological Survey, 1998. Helmsdale. Scotland Sheet 103E. Solid and Drift. 1:50 000 Geology Series. British Geological Survey, Keyworth, Nottingham.

British Geological Survey, 2002. Golspie. Scotland Sheet 103W. Solid and Drift. 1:50 000 Geology Series. British Geological Survey, Keyworth, Nottingham. 
Brookfield, M.E., 1976. The age of the Allt na Cuile Sandstones (Upper Jurassic,

Sutherland). Scottish Journal of Geology 12, 181-186.

Buckman, S.S., 1923. Type ammonites Volume 4, London.

Chesher, J.A., Lawson, D., 1983. The geology of the Moray Firth. Report of the Institute of Geological Sciences, No. 83/5.

Cope, J.C.W., 1980. A correlation of the Jurassic rocks of the British Isles. Part Two: Middle and Upper Jurassic, Geological Society of London Special Report.

Cox, B.M., Sumbler, M.G., 2002. British Middle Jurassic Stratigraphy. Geological

Conservation Review Series No. 26. Joint Nature Conservation Committee/Chapman and

Hall, Peterborough.

Hudson, J.D., 1962. The Great Estuarine Series (Middle Jurassic) of the Inner Hebrides.

Unpublished $\mathrm{PhD}$ thesis, University of Cambridge.

Hudson, J.D., Trewin, N.H., 2002. Jurassic, In: Trewin, N.H. (Ed.), The geology of Scotland. Geological Society of London, London, pp. 323-350.

Hurst, A.R., 1981. Mid Jurassic stratigraphy and facies at Brora, Sutherland. Scottish Journal of Geology 17, 169-177.

Johnstone, G.S., Mykura, W., 1989. British Regional Geology: the northern Highlands of Scotland, 4th ed. HMSO for British Geological Survey, London.

Judd, J.W., 1873. The secondary rocks of Scotland. Quarterly Journal of the Geological Society of London 29, 97-195.

Lee, G.W., 1925. Mesozoic rocks of East Sutherland and Ross, In: Read, H.H., Ross, G., Phemister, J. (Eds.), The geology of the country around Golspie, Sutherlandshire. Memoir of the Geological Survey, pp. 65-114.

Lee, G.W., Pringle, J., 1932. A synopsis of the Mesozoic rocks of Scotland. Transactions of the Geological Society of Glasgow 19, 158-224.

Macgregor, M., Read, H.H., Manson, W., Pringle, J., 1930. East Sutherland field meeting : July 27th-August 7th, 1929. Proceedings of the Geologists' Association 41, 63-86.

MacLennan, A.M., Trewin, N.H., 1989. Palaeoenvironments of the late Bathonian-mid Callovian in the Inner Moray Firth, In: Batten, D.J., Keen, M.C. (Eds.), Northwest European Micropalaeontology and Palynology. British Micropalaeontological Society Series. Ellis Horwood Limited, Chichester.

McQuillan, R., Donato, J.A., Tulstrup, J., 1982. Development of basins in the inner Moray Firth and the North Sea by crustal extension and dextral displacement of the Great Glen Fault. Earth and Planetary Science Letters 60, 127-139.

Murchison, R.I., 1829a. On the coalfield of Brora. Transactions of the Geological Society of London 2, 293-326.

Murchison, R.I., 1829b. Supplementary remarks on the strata of the Oolitic Series, and the rocks associated with them in the counties of Sutherland and Ross, and in the Hebrides.

Transactions of the Geological Society of London 2, 353-368.

Neves, R., Selley, R.C., 1975. A review of the Jurassic rocks of north-east Scotland, In: Finstad, K.G., Selley, R.C. (Eds.), Jurassic Northern North Sea Symposium (JNNSS75). Norsk Petroleumsforening, Oslo, Stavanger, pp. 5/1-29.

Pickering, K.T., 1984. The Upper Jurassic 'Boulder Beds' and related deposits: a faultcontrolled submarine slope, NE Scotland. Journal of the Geological Society of London 141, 357-374.

Rawson, P.F., Allen, P.M., Brenchley, P.J., Cope, J.C.W., Gale, A.S., Evans, J.A., Gibbard, P.L., Gregory, F.J., Hailwood, E.A., Hesselbo, S.P., Knox, R.W.O.B., Marshall, J.E.A., Oates, M., Riley, N.J., Smith, A.G., Trewin, N., Zalasiewicz, J.A., 2002. Stratigraphical Procedure. Geological Society, London. 
Richards, P.C., Lott, G.K., Johnson, H., Knox, R.W.O.B., Riding, J.B., 1993. 3. Jurassic of the Central and Northern North Sea, In: Knox, R.W.O.B., Cordey, W.G. (Eds.), Lithostratigraphic nomenclature of the UK North Sea. British Geological Survey, Nottingham.

Riding, J.B., 2005. Middle and Upper Jurassic (Callovian to Kimmeridgian) palynology of the onshore Moray Firth Basin, northeast Scotland. Palynology 29, 87-142.

Simms, M.J., Chidlaw, N., Morton, N., Page, K.N., 2004. British Lower Jurassic

Stratigraphy. Geological Conservation Review Series No. 30. Joint Nature Conservation

Committee/Chapman and Hall, Peterborough.

Stephen, K.J., Davies, R.J., 1998. Documentation of Jurassic sedimentary cycles from the Moray Firth Basin, United Kingdom North Sea, In: Graciansky, P.-C., Hardenbol, J., Jacquin, T., Vail, P.R. (Eds.), Mesozoic and Cenozoic Sequence Stratigraphy of European Basins. SEPM Special Publication 60, pp. 481-506.

Sunderland, J., 1972. Deep sedimentary basin in the Moray Firth. Nature 236, 24-25. Sykes, R.M., 1975. The stratigraphy of the Callovian and Oxfordian stages (Middle and Upper Jurassic) in northern Scotland. Scottish Journal of Geology 11, 51-78. Trewin, N.H., Hurst, A.R., 1993. Excursion guide to the geology of east Sutherland and Caithness. Scottish Academic Press, Edinburgh.

Waters, C.N., Gillespie, M.R., Smith, K., Auton, C.A., Floyd, J.D., Leslie, A.G., Millward, D., Mitchell, W.I., McMillan, A.A., Stone, P., Barron, A.J.M., Dean, M.T., Hopson, P.M., Krabbendam, M., Browne, M.A.E., Stephenson, D., Akhurst, M.C., Barnes, R.P., 2007. Stratigraphical Chart of the United Kingdom: Northern Britain. British Geological Survey. Wignall, P.B., Pickering, K.T., 1993. Palaeoecology and sedimentology across a Jurassic fault scarp, NE Scotland. Journal of the Geological Society of London 150, 323-340. Woodward, H.B., 1905. Quoted Final report of the Royal Commission on coal supplies, part 6 (Scotland).

Wright, J.K., Cox, B.M., 2001. British Upper Jurassic Stratigraphy. Joint Nature Conservation Committee/Chapman and Hall, Peterborough. 


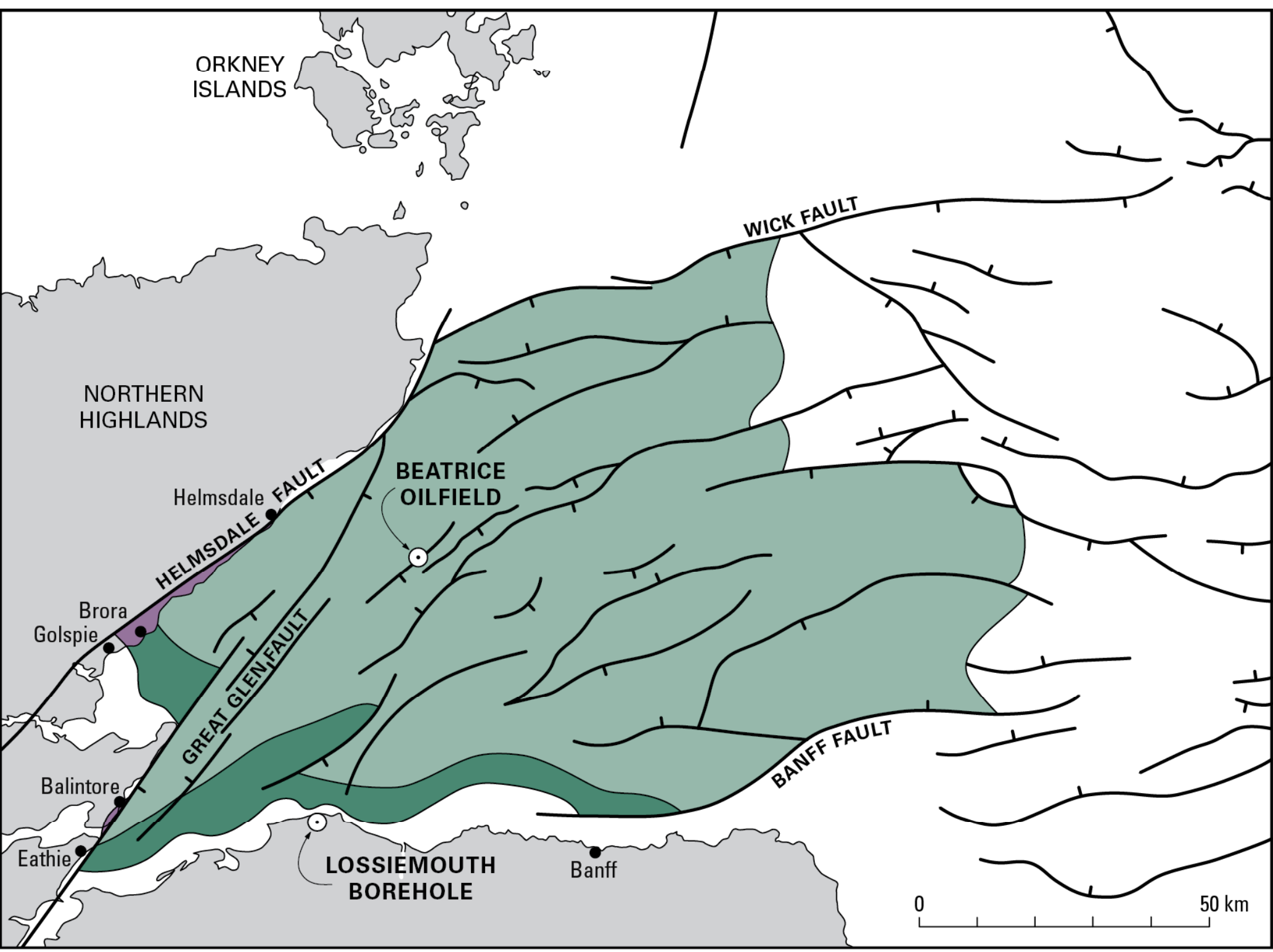

Jurassic strata present offshore

Jurassic strata at outcrop onshore

Jurassic strata at outcrop offshore

$\longrightarrow$ Faults 


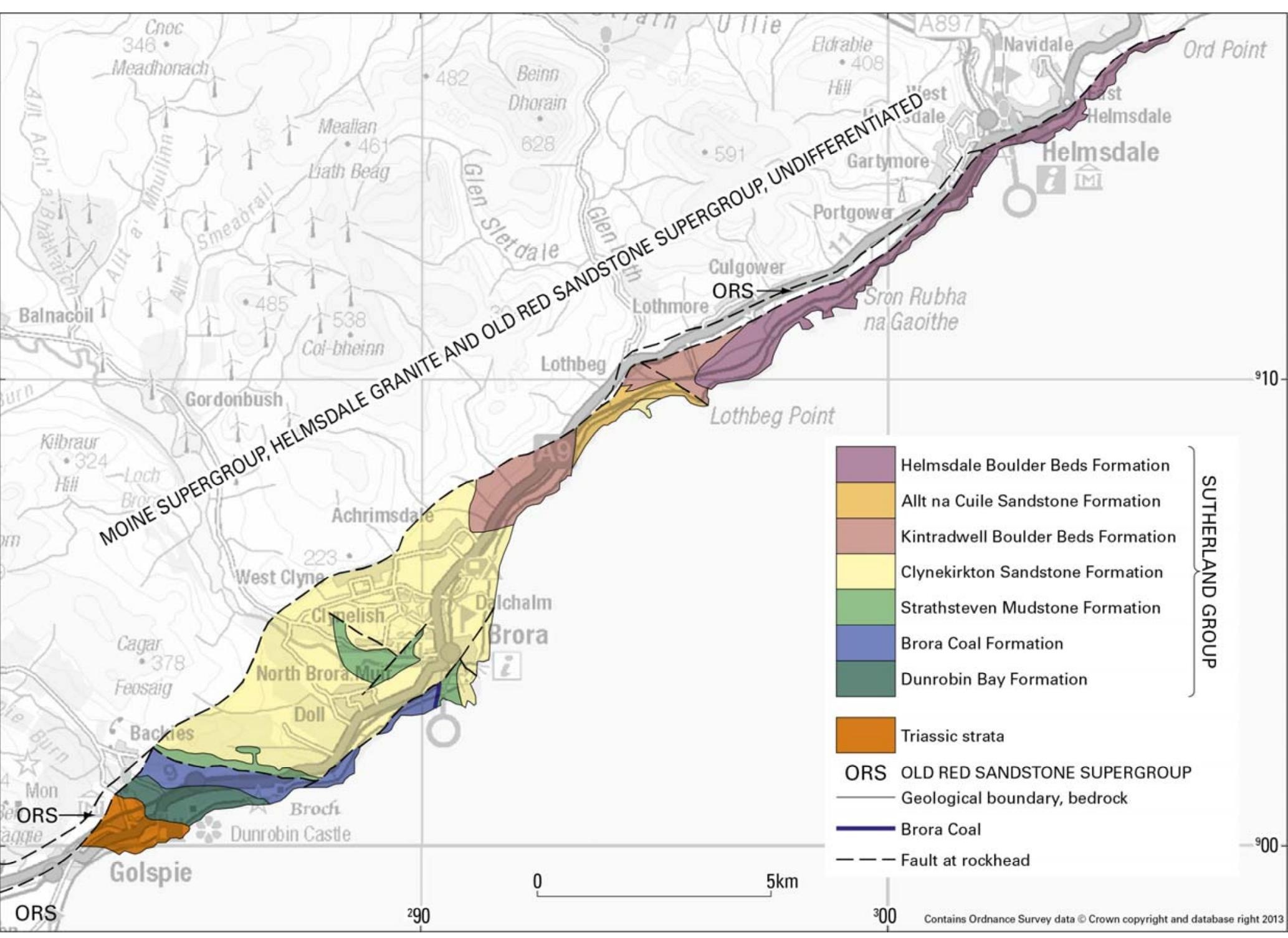


